\title{
Normative language policy and minority language rights: rethinking the case of regional languages in France
}

\author{
Leigh Oakes ${ }^{1}$ (D)
}

Received: 2 April 2016/ Accepted: 16 June 2016/Published online: 27 July 2016

(C) The Author(s) 2016. This article is published with open access at Springerlink.com

\begin{abstract}
Building on the emerging notion of 'normative language policy', this article seeks to contribute to the further development of an integrated framework for researching the ethics of language policy and planning. Using the case of minority language rights in France as an example, it demonstrates the benefit of combining context-sensitive or empirical approaches as traditionally used in language policy and planning research with a nuanced normative ethical analysis as employed in political philosophy and political theory. After outlining the foundational work on minority rights that has emerged within contemporary liberal theory in particular, it considers some limitations of this work in the French context specifically. It then examines ways that recent theoretical advances in liberal theory can nonetheless shed new light on the minority languages debate in France. It concludes with a critical overview of a new model for the management of the country's regional languages recently proposed within republican theory, as a further example of the benefits of a normative language policy approach.
\end{abstract}

Keywords Normative language policy - Language ethics · Minority language rights $\cdot$ France

\section{Introduction}

The critical 'turn' that came to transform language policy and planning (LPP) research from the 1970s (Ricento 2000: 200-203) has usefully served to highlight the power inequalities inherent in many state language policies. However, the further development of LPP as a field of study can benefit from a 'rediscovery' of its

Leigh Oakes

1.oakes@qmul.ac.uk

1 School of Languages, Linguistics and Film, Queen Mary University of London, Mile End Road, London E1 4NS, UK 
pragmatic origins, moving it beyond the mere critique of existing power structures to more constructive or practical analyses. Indeed, the politics of language inevitably involves power relations which cannot be entirely eliminated; nor should they be necessarily. This raises the unavoidable question of which power relations are justified and which are not. For all their negative connotations, normative approaches to LPP are not inherently wrong; interventions in language matters can be just or unjust, depending on the aims, the methods used, the outcomes, and so on. In this respect, LPP research can benefit from techniques developed within so-called normative analytic political philosophy, especially considering the latter's recent interest in language rights and linguistic justice more broadly (e.g. Patten 2001, 2014; Kymlicka and Patten 2003; De Schutter 2007; Van Parijs 2011; Ricento et al. 2014; Peled and Weinstock in press). With its principled approach to the study of ethics, the emerging notion of 'normative language policy' provides analytical tools for weighing up the diverse range of moral questions associated with LPP matters, including those related to minority language rights. It asks questions like: On what ethical grounds can one argue in favour of recognising minority languages? What types of policies are morally permissible? And what would a linguistically fair outcome for speakers of minority languages look like? But if the strength of such an approach lies in its broadly applicable abstract principles, political philosophy can also gain from the more contextualised or grounded approaches traditionally employed in LPP research. As Edwards (2003: 551) explains, 'at some point a welcome marriage is to be anticipated between generalized and disinterested "philosophical" perspectives and the real-life settings that have given them life and that require their attention. This implies, in turn, an interdisciplinarity that would connect insights from several scholarly bases.'

This article aims to contribute to the further fostering of such interdisciplinarity, by applying a normative language policy approach to a real-world LPP context. Building on other attempts to propose a more integrated framework for the moral evaluation of language policies (e.g. Oakes and Peled forthcoming), it revisits the much-discussed case of regional languages in France. After outlining the foundational work on minority rights that has emerged within contemporary liberal theory in particular, it considers some limitations of this work in the French context specifically. It then explores ways that recent theoretical advances in liberal theory can nonetheless help to reconceptualise the minority languages debate in France. It concludes with a critical overview of a new model for the management of France's regional languages recently proposed within republican theory, as a further example of the benefits of normative theorising for LPP research.

\section{Minority rights and liberal theory}

Liberal theory is a political philosophy centred on the notion of individual freedom. In the post-WWII period, it especially emphasised the non-interference of the state in individual autonomy, the right of individuals to lead their lives more or less according to their own interpretation of the good life (e.g. Rawls 1971). In the private sphere, this meant that individuals were generally perceived as being free to 
make their own choices, for example regarding the language used in the home or in private communications. In the public sphere, this implied a position of neutrality or 'benign neglect' on the part of the state, with a view to protecting the formal equality of citizens in the name of universal values. The state was considered blind to any differences amongst individuals, according the same political rights to all.

This procedural or atomistic understanding of liberalism came under increasing pressure in the 1980s-1990s as a result of so-called communitarian critiques. According to the communitarian perspective, universalist conceptions of justice are not prior to particular and contextual conceptions of the good. Individuals are not isolated or unencumbered moral agents, but rather 'constituted' by or 'embedded' in communities (Sandel 1982). These communities provide the shared goods that form the basis of identity, which acts as 'the background against which our tastes and desires and opinions and aspirations make sense' (Taylor 1994: 33-34). Provoking intense reflection in the liberal camp itself, these communitarian critiques ultimately contributed to the advent of a new intermediary branch of liberalism which has been termed 'cultural liberalism'.

Without a doubt, the most important figure in the development of this new branch of liberal theory is the Canadian philosopher Will Kymlicka. In his seminal work Multicultural Citizenship, Kymlicka (1995) advances the idea that culture represents a 'social primary good', a concept coined by Rawls to refer to the social goods that every rational person is presumed to want for the pursuit of the good life-rights, liberties, powers, opportunities, income, wealth, and so forth. While Rawls makes no mention of culture or language, Kymlicka insists that an individual's free choice is in fact predicated on their participation in what he calls a 'societal culture', which he defines as:

a culture which provides its members with meaningful ways of life across the full range of human activities, including social, educational, religious, recreational, and economic life, encompassing both public and private spheres. These cultures tend to be territorially concentrated, and based on a shared language. (Kymlicka 1995: 76, emphasis added)

To Kymlicka's mind, 'societal cultures' are thus necessary to maintain 'contexts of choice', essential for the individual autonomy that is a core tenet of liberal theory.

Such societal cultures exist even in liberal states that claim to adopt a position of neutrality in the public sphere. As Kymlicka (1995: 108) notes, '[g]overnment decisions on languages, internal boundaries, public holidays, and state symbols unavoidably involve recognizing, accommodating, and supporting the needs and identities of particular ethnic and national groups. The liberal state unavoidably promotes certain cultural identities, and thereby disadvantages others.' It is in this sense that communitarian philosophy criticises procedural liberalism for being 'a particularism masquerading as the universal' (Taylor 1994: 44). Indeed, the state inevitably plays a role in promoting a certain culture in the public sphere, and this is especially evident concerning official language choices.

To counteract this inherent bias, Kymlicka proposes the notion of 'groupdifferentiated rights', accorded on the basis of cultural membership. Kymlicka is interested first and foremost in national minorities, like the Quebecers in Canada, 
whom he argues should be granted what he calls 'self-government rights'. He contrasts these rights with the less extensive 'polyethnic rights' which should be granted to immigrants. Finally, a third category of rights-special representation rights - guarantee certain places for minorities in the institutions of the overarching state, usually on a temporary basis as a transitionary measure. While these three types of group-differentiated rights may be 'accorded to the individual members of the group, or to the group as a whole, or to a federal state/province within which the group forms the majority' (Kymlicka 1995: 45), they are nonetheless clearly distinguished from 'collective rights'. Whereas the moral agents for collective rights are groups, the ethical justification for Kymlicka's 'group-differentiated rights', crucially, still rests in that fact that they are designed to meet the needs of individuals.

Another pivotal aspect of Kymlicka's model lies in the distinction he makes between two types of measures used by minorities: so-called 'external protections' and 'internal restrictions'. External protections relate to intergroup relations and allow minorities to protect their distinct identities by limiting the impact of the decisions of the larger society within which they exist. Internal restrictions, by contrast, involve intragroup relations and refer to attempts by minorities to restrict the freedoms of their own members in the name of group solidarity. As an example, Kymlicka mentions how some minorities might discriminate against girls in the provision of education, or deny women the right to vote or hold office (Kymlicka 1995: 153). As these measures do not protect the minority from the decisions of the larger society, they should be rejected by liberals, who should only countenance group-differentiated rights that seek external protections. So how does Kymlicka's model of multicultural citizenship apply to the question of regional linguistic minorities in France?

\section{Limitations of Kymlicka's model in the French context}

While the model would seem to work well in the Canadian context in which it was conceived, that does not necessarily mean it can apply equally to other contexts. As Schnapper remarks:

The multiculturalism of Canada, with its indigenous peoples, two founding peoples and immigrant communities, which inspires Kymlicka's thinking, is not the same sort of 'multiculturalism' as that of a unitary nation like France. One cannot neglect the history of the nation's formation or the legitimacy of political order for the sake of adopting policies to recognise cultural rights.

(Schnapper 2000: 246)

The two differences that Schnapper identifies-historical and political in naturepoint to two drawbacks of Kymlicka's framework when applied to France, as examined briefly in the following two sections. 


\section{Societal cultures}

One obvious problem with Kymlicka's model relates to the key concept of 'societal culture'. While Quebecers in Canada clearly constitute such a culture, this cannot be said to be the case for France's regional linguistic minorities which have undergone a historical process of assimilation (Ager 1999: 35). ${ }^{1}$ As 'cultural groups marginalised following their annexation to the French nation' (Guérard de Latour 2009: 82), the majority of France's regional linguistic minorities would seem to fall into the category of national minorities. However, it would be difficult to claim that they enjoy a societal culture of the type envisaged by Kymlicka, which is one that 'provides its members with meaningful ways of life across the full range of human activities [...] encompassing both public and private spheres' (Kymlicka 1995: 76, emphasis added). While this may have been the case in the past, it is not so today, with the possible exception of Corsica.

Over the last three decades, Corsica has succeeded in gaining a fair degree of autonomy or self-government rights. In 1982, it was granted the status of territorial collectivity, with a new Corsican Assembly possessing greater powers than the regional councils on the mainland. Despite staunch opposition from republicans on both sides of the political spectrum, more self-government measures followed in 2000 as a result of the Matignon Accords (Blackwood 2008: 91-94; Oakes 2011a). With regard to language, the Corsican authorities have voted on several occasions since the 1980s to grant official status to Corsican. Most recently, in May 2013, the Corsican Assembly passed its Propositions pour un statut de co-officialité et la revitalisation de la langue corse, which envisage the use of Corsican in all domains of public, economic and social life (Collectivité territoriale de Corse 2013a). Notwithstanding the fact that this would require a Constitutional amendment, the Corsican authorities recognise the long-term nature of the goal (Collectivite territoriale de Corse 2014: 17). While their own study of language attitudes and language competence conducted in 2012 estimated the number of speakers of Corsican to be between 28 and $42 \%$ of the island's population, they recognised the potential over-evaluation of both competence and linguistic practice on account of the self-reporting method used (Collectivité territoriale de Corse 2013b: 55). Indeed, a useful counterbalance is provided by the fact that only $23 \%$ of respondents chose to fill the questionnaire out in Corsican, and only $10 \%$ continued in Corsican right until the end. This latter figure leads the Corsican authorities to estimate a mere 30,000 'good speakers' of Corsican at the present time (Collectivite territoriale de Corse 2013b: 59-62). The idea of a societal culture sustained by the Corsican language thus remains a distant prospect.

\footnotetext{
1 This is a criticism that has been made more broadly of Kymlicka's model: 'Treating the Québécois as the norm for national minorities and (non-immigrant) cultural minorities incapable of sustaining their societal cultures as exceptional hard cases both misrepresents the empirical situation and weakens the normative claims of the vast majority of (non-immigrant) ethnic and linguistic minorities' (Carens 2000: 64).
} 


\section{Normative differences}

The second problem alluded to by Schnapper relates to the normative differences between Kymlicka's liberalism and French republicanism. At the heart of French republicanism is the notion of universalism. The two key principles that uphold this ideal are clearly expressed in the Constitution: France is an 'indivisible Republic' ensuring the 'equality of all citizens before the law, without distinction of origin, race or religion' (art. 1). These principles lie behind France's traditional refusal to recognise any minority groups on its territory (see Oakes 2011b). They were invoked, for example, in the Conseil constitutionnel's famous rejection in 1992 of the idea of a 'Corsican people, component of the French people' (Decision 91-290 DC of 9 May 1991, Rec. 13). They are also in large measure responsible for France's rejection to date of the European Charter for Regional or Minority Languages (Määttä 2005; Judge 2007: 140-144). Despite the Charter's specific intention to promote minority languages rather than linguistic minorities, the Conseil constitutionnel ultimately blocked France's ratification in 1999 on the grounds that the Charter did indeed, in its view, "confer specific rights on "groups" of speakers of regional or minority languages within "territories" in which these languages are used' (Decision 99-412 DC of 15 June 1999, Rec. 10).

Now it is true that the moral ideals underpinning the French republican model are often misunderstood, especially in anglophone circles (see Cohen 2001; Birnbaum 2004). Considering its unique historical development, some commentators claim that French republicanism cannot be analysed using imported 'Anglo-Saxon' concepts (Koubi 2004: 198). Such comments clearly refer to liberalism, including Kymlicka's version of liberalism; but they equally apply to republican political thought as theorised elsewhere. Indeed, in many respects, 'Republicanism in France may seem to have "gone native" to the point of blurring any "family resemblance" with other republican traditions' (Laborde 2008: 3). In debates of models of civicrepublicanism developed in the Anglo-American world, for example, some have stressed the need to appreciate the necessarily utopian nature of such philosophies, 'that in practice we have no choice but to settle for scaled-down and less ambitious forms of civic life' (Beiner 2003: 7). As Beiner (2003: 6) notes:

basic features of social and political life in the modern world militate strongly against the realization of such an ideal. We live in large and complex societies. All of us are deeply immersed in the demands of our private lives, which rarely provide the huge measures of leisure and disinterestedness that a fully committed civic-mindedness would require. We belong to subgroups tied to particularistic and very real interests that draw us away from shared politywide interests.

So why has French republicanism, unlike liberalism and republicanism as theorised elsewhere, not been able to adapt itself to the new circumstances of modern life, including the realities of ethnic diversity? As Laborde explains, the answer lies in part in the fact that 'French republicanism, by contrast, is better conceived of as a "public philosophy" or national ideology, mostly articulated and diffused by public intellectuals, politicians, and the media' (Laborde 2008: 25). As 
an ideology rather than a philosophy per se, it does not have the capacity for normative political analysis of the type that engages in objective self-criticism.

It is nonetheless worth remembering that liberalism and French republicanism share a commitment to a universalist conception of political justice (Audard 1999). If Kymlicka's model of multicultural citizenship was able to transcend the overly abstract universalism characteristic of more procedural conceptions of post WWIIliberalism without losing sight of its core ideals, then it is well placed to help French republicanism undergo a similar transformation, thereby creating an equivalent philosophical capacity through the encouragement of theoretical advancements rather than ideological entrenchments. The next section considers four ways that contemporary liberal theory can make important contributions to the regional language debate in France.

\section{Liberal contributions to the regional languages debate}

\section{Focus on the individual}

The first has to do with the focus on the individual. Such a perspective allows a liberal approach to draw attention to the actual burdens that are placed on members of linguistic minorities if they are not offered certain accommodations to offset the choice of another language as the official language of the state. Patten (2014) refers to arguments used to justify accommodations on such grounds as minorityregarding reasons of principle. He contrasts these with what he calls third-partyregarding and impersonal reasons of principle.

Third-party-regarding reasons do not, in arguing for a particular accommodation, privilege the standpoint of individuals belonging to the cultural minority that would enjoy the accommodation. Instead they refer to the interests of some other or broader group, typically all members of the society in question or even all people in the world. At the limit, the claim made in appealing to such a reason is that everyone would benefit if some particular accommodation were to be made. Impersonal reasons depart even more radically from minority-regarding ones. Unlike both minority-regarding and third-party-regarding reasons, they invoke a kind or dimension of value that is not ultimately reducible to the interests or well-being of individuals. The claim made in offering such a reason is that the failure to extend an accommodation would result in a loss of value in the world that does not reduce to the diminished prospects of individual persons. (Patten 2014: 18)

As seen above, France explicitly rejects in principle an approach conceived in terms of minority group rights. In practice, this has also led it to reject an approach that focuses on the individual rights of the members of such groups. Instead, France has opted for something between a third-party-regarding approach and an impersonal approach as described by Patten and that centres on the idea of cultural heritage. Consistent with republican thinking, the chosen approach is supported even by some French linguists, whose views appear somewhat surreal to non- 
republican ears. For example, Bernard Cerquiglini, who famously identified 75 languages that would qualify for protection if France ratified the Charter for Regional or Minority Languages, did not hesitate to claim that the Charter promotes a vision which is contrary to republican principles, "which hold that language, as an element of culture, belongs to the national heritage; Corsican is not the property of the Corsican region, but of the nation' (Cerquiglini 1999a: 4). Illustrating the approach further, Cerquiglini explains that 'alongside literary and artistic heritage and historical monuments, there are also languages that have the same value as a Roman church, if not a cathedral' (Cerquiglini 1999b). Even many proponents of ratifying the Charter maintain that regional languages should be promoted purely on the grounds that they belong to the 'undivided cultural heritage of France' (Carcassonne 1998: 128). This is a view that has come to form the cornerstone of official policy towards regional languages in France today, as evidenced by the constitutional amendment of 2008 which states that '[r]egional languages belong to the heritage of France' (art. 75-1).

The problem with such a third-party-regarding/impersonal approach to regional languages is that, by shifting the focus away from the needs of the speakers of these languages, it exposes itself to a number of weaknesses. Indeed, Patten is sceptical that such an approach would sufficiently obligate a state concerned with individual autonomy to produce a beneficial outcome for individuals belonging to cultural minorities.

Individual autonomy does depend on the availability of what Mill [1991 [1859]: 64] calls a 'variety of situations' and Raz [1986: 372] terms an 'adequate range of options.' But an adequate range of options is not the same as a maximal one. (Patten 2014: 19)

In other words, the state is under no obligation to provide a diversity of options $\mathrm{ad}$ infinitum. If the cultural diversity of a given society is deemed to be sufficiently rich, how does the promotion of yet more diversity of a linguistic nature enhance individual autonomy further?

Third-party-regarding/impersonal arguments justified on cultural heritage grounds are also more vulnerable to counterarguments based on financial or costbenefit considerations. As Patten again notes:

Accommodation policies involve money, time, political energy, and institutional capacity, and they have to translate somehow into accessible options if they are to produce the advertised benefits. Perhaps these resources would produce even greater general benefits if they were used differently? Investments in the arts and education, and support for civil society and for research and development efforts by the private sector, seem like alternative ways of encouraging a greater diversity of options. It is not enough for proponents of the third-party-reasons approach to show that cultural accommodations would produce some general benefits. They have to show that those accommodations would produce greater (or at least equivalent) benefits than any alternative, permissible use of the resources that would be expended. (Patten 2014: 19-20) 
While cost-benefit arguments are clearly important factors to consider when evaluating language claims (see Grin 2005; Bruthiaux 2009), the reality is that a third-party-regarding/impersonal approach means that linguistic minorities could find themselves having to compete with artists, theatres, orchestras, museums and the like for the normally limited resources devoted to cultural heritage. Moreover, putting regional languages on a par with other aspects of cultural heritage in this way is potentially reductive. As Giordan (2008: 29) warns: 'Regional languages would no longer be a living, evolving reality, but would become vestiges for at most a few people curious about old traditions.' This risk of folklorisation is all the more real considering that official action to promote regional languages in France has traditionally been limited to the domains of culture, the media and education, the latter regarding mostly the teaching of, rather than in, regional languages.

Liberal approaches do not suffer from any of these weaknesses. By emphasising the role of the individual, a liberal conception of justice can help to refocus attention on the real issue of concern, namely the actual burdens and disadvantages faced by individual members of linguistic minorities beyond their role as citizens. So what are these burdens and disadvantages that members of linguistic minorities suffer? This question can be addressed by looking at the second aspect of liberalism that is useful for thinking about minority language rights, namely the idea of cultures being associated with options.

\section{Cultures and options}

In his essay Considerations on Representative Government, the 19th-century liberal philosopher John Stuart Mill argued that it was more advantageous for France's linguistic minorities to assimilate into the greater French societal culture.

Nobody can suppose that it is not more beneficial to a Breton, or a Basque of French Navarre, to be brought into the current of the ideas and feelings of a highly civilised and cultivated people-to be a member of the French nationality, admitted on equal terms to all the privileges of French citizenship, sharing the advantages of French protection, and the dignity and prestige of French power-than to sulk on his own rocks, the half-savage relic of past times, revolving in his own little mental orbit, without participation or interest in the general movement of the world. (Mill 1991 [1861]: 294-295).

In other words, Mill believed that French culture offered linguistic minorities a much fuller range of options to realise their individual autonomy than did their respective cultures of origin. Far from being limited to traditional liberal thought, this view is also shared by many French republicans, who see in the acquisition of a 'universal' civic culture a means of liberating oneself from the limitations of one's ethnicity. To be sure, the same arguments can still be heard today amongst some liberals. For example, the liberal egalitarian critique of multiculturalism has argued that the maintenance of minority languages acts as a barrier to equality of opportunity and therefore to the range of options available to individuals (e.g. Schlesinger 1998; Barry 2001). 
There is nonetheless an irony here in so far as such arguments that seek to increase opportunities for individuals actually advocate a restriction of their linguistic options. As Petrovic (2015: 38) notes, 'in a form of liberal double-speak, an increase in linguistic options shuts doors, hampering equality and freedom, while limiting one's linguistic options promotes these liberal ideals.' He argues that such 'language-negative liberalism' results from particular interpretations-one might even say misinterpretations - of certain principles of liberal theory (Petrovic and Kuntz 2013: 133). For example, the notion of adequacy with regard to the range of options that the liberal state is obliged to provide is frequently understood in a generic or universalist sense: 'The assumption is that certain sorts of options are valuable for people no matter what their particular goals or preferences happen to be' (Patten 2014: 92). But there is another way of looking at the notion of adequacy in this context that incorporates a subjective dimension. In other words, having specific options that particular individuals care about is part of what is means to have an adequate range of options.

Patten identifies two ways that loss of a culture may leave individuals with an inadequate range of subjectively valued options. The first has to do with the idea of cultures as option generators. As already mentioned, Kymlicka's notion of a societal culture as a context of choice cannot feasibly apply to France's regional linguistic minorities at the present time. But the concept of societal culture has also been criticised for its inability to address the legitimate moral claims of small and vulnerable cultural minorities (Carens 2000: 61-64). Indeed, all cultures, whatever their size, generate options for their members. As Patten explains with particular regard to language, '[i]t is not unusual for people who belong to the same linguistic community to share preferences for particular options, practices, styles, and so on' (Patten 2014: 202). Careful not to fall into the trap of essentialising culture, Patten recognises that cultures vary significantly in time and space. He nonetheless maintains that 'the frequency with which certain preferences are held may be much greater within a particular linguistic group than outside of it.' The example of particular music styles and performers he cites calls to mind the case of Corsican music, including polyphonic song, which has grown significantly in popularity since the revival of Corsican culture that began with the riacquistu of the 1970s (Meistersheim 2008). Patten concludes that:

people with preferences that are distinctive of their linguistic community have a good reason to care about the ongoing success of that community. The options they care about are more likely to remain available if their language community survives and flourishes than if its members assimilate into another language group. (Patten 2014: 202-203)

The second way that cultures are associated with options stems not from the fact that cultures generate options that have subjective value so much as because they are valued for their own sake. Wanting to see their culture flourish can be a subjectively valued option that many individuals deem necessary for the realisation of their conception of the good life. One need only look at the results of languageattitude studies to realise that regional languages in France today are on the whole highly valued by their speakers. For example, the recent study of language attitudes 
in Corsica mentioned earlier found that $86 \%$ of respondents expressed a significant interest in the Corsican language, while $90 \%$ considered that French-Corsican bilingualism was the way forward for the island (Collectivité territoriale de Corse 2013b: 48). The majority of respondents (72\%) also thought that policies in favour of Corsican were moving in the right direction, but that more could nonetheless be done $(54 \%)$. Interestingly, on these last two points, it was the participants aged 18-24 who held the strongest views.

In short, when considering the options that actual individuals value on a more subjective level, one can start to see why members of linguistic minorities might face a sort of 'options disadvantage' if their language is not given fair opportunity to flourish (Patten 2014: 69-72). The case of regional languages in France provides a prime example of traditionally unfair background conditions, thus making arguments based on subjective inadequacy of options all the more relevant.

\section{Internal restrictions and the teaching of regional languages}

The third aspect of liberalism that can be of benefit for thinking about minority language rights concerns Kymlicka's notion of internal restrictions, which potentially comes into play in the French context regarding the teaching of regional languages. Since this was first permitted in the public sector by virtue of the Deixonne Law of 1951 (Ager 1999: 31; Blackwood 2008: 47-49), it has been repeatedly argued that such teaching must necessarily remain optional as a matter of principle (Judge 2007: 125-145), French being the language of the Republic and thus of the state education system (Law No. 94-665 of 4 August 1994 relative to the use of the French language, art. 1). Any mandatory teaching of a regional language in a particular area would amount to unequal treatment of schoolchildren throughout the Republic. Indeed, this was the argument made by many Republicans when debating the Matignon Accords, which included proposals for making Corsican classes part of the normal nursery and primary school curriculum with an opt-out provision for parents (Blackwood 2008: 92; Oakes 2011a: 72-73). In particular, some commentators cited the hypothetical case of the children of Breton civil servants or Moroccan agricultural workers living in Corsica temporarily who would be forced to study a language which was not their own, 'because no family would dare request an exemption' (Kahn 2000). The implication, of course, was that such an imposition constituted what Kymlicka would call an internal restriction.

There is nonetheless a fallacy here in so far as the state in fact restricts a whole range of freedoms of its citizens, restrictions that are seldom contested on moral grounds.

In all countries, no matter how liberal and democratic, people are required to pay taxes to support public goods. Most democracies also require people to undertake jury duty, or to perform some amount of military or community service, and a few countries require people to vote (e.g. Australia). (Kymlicka 1995: 36) 
Schooling, too, is mandatory in most states between certain ages, and school children are usually required to take certain subjects. In France, this includes philosophy in the final year of lycée for those on general streams, and the learning of two foreign languages in collège, the second of which may ironically be a regional language. Far from considering such measures as restrictions on individual freedom of choice, liberals would argue that the state has in this respect a 'paternalistic duty' towards children, independent from that of their parents, so as to ensure they have the greatest range of reasonable options when they come of age and are able to make their own informed choices (e.g. Gutmann 1980; Kymlicka 1995: 216). Seen from this perspective, the learning of languages is not a subtractive but an additive process, the aim of which is to increase options and linguistic repertoires, not to restrict them. Some may argue on instrumentalist grounds that precious classroom time is better spent learning languages of wider communication. Notwithstanding the potentially reductive nature of such arguments - which, if followed through to their logical conclusion would favour the adoption of a single global lingua francasuch reasoning also completely ignores the other benefits of language learning, which apply equally to regional languages. The Corsican authorities, for example, argue that, as a symbol of the island's identity, the Corsican language is an important means of social cohesion for speakers and non-speakers alike (Collectivité territoriale de Corse 2013a, 2014).

Even for the hypothetical child of a Breton civil servant or Moroccan agricultural worker who may eventually move elsewhere, there are significant cognitive, educational and social benefits of learning of any language. To cite but one example, the learning of a regional language improves one's ability to learn other languages, including French. As the Breton-language school network observes:

far from being 'linguistically disabled' as some would have us believe, Diwan pupils not only master Breton and French perfectly-with results in French well above the national average! - but also learn a third even fourth language much more easily. (Nadeau n.d.)

Combined with the fact that the teaching of French has never been questioned, even in immersion schools, it is difficult to see how such an increase in potential options could ever constitute an internal restriction as defined by Kymlicka. Indeed, this concept is useful in the French context precisely for its ability to help republicans see beyond their concern that the mandatory teaching of regional languages would allow group rights to have precedence over individual rights.

\section{Ethnocultural non-neutrality of the state}

The final contribution that contemporary liberal theory can make to the French debate on regional languages concerns the observation made by Kymlicka and others that the state is not ethnoculturally neutral. Indeed, many academic commentators both in and outside France have noted how French Republicanism has in many respects fallen victim to ideological excesses with regard to the claim to neutrality, leading it paradoxically to exhibit features in practice that it expressly rejects in principle. For example, Jennings (2000: 597) reflects on whether French 
republicanism should in fact be seen as 'a perverse form of communitarianism, for which the national community is the supreme community, forcibly imposing a unitary common good over the plurality of sub-national groups'. He asks: 'To what extent does the republican conception of citizenship embody a truly universalist commitment, as opposed to a particularist articulation of national values?' (Jennings 2000: 597). In a similar manner, others speak of a 'republican fundamentalism' or 'national universalism' (Baubérot 2006) and note that 'Jacobin Republicans who relentlessly denounce minority claims are most often unconscious nationalists' (Seymour 2000: 126). Others still point out that strict interpretations of the ideals of equality and universality that reject expressions of cultural diversity in the public sphere have effectively given rise to a 'tightly-knit ethnicity' (Bouchard 1999: 40), a 'republican ethnicity' (Geisser 2005), some might say.

The 1992 constitutional amendment that declared French the 'language of the Republic' and which has become another major obstacle to the promotion of regional languages is considered by some as an example of this republican fundamentalism that paradoxically 'undermines the universalist characteristics of the French Republican model' (Giordan and Lafont 1999). By giving constitutional status to a cultural characteristic, the amendment is thus said to betray civic principles, equating to an 'ethnicisation of our conception of the nation' (Woehrling 1999: 21; see also Renaut 2000: 390-391). Such arguments are all the more convincing since the amendment was introduced at the very time that France refused to ratify the Charter for Regional or Minority Languages. Cultural liberalism would argue that regional languages should be granted some recognition in the public sphere to compensate for the bias whereby only the language of the majority is granted official status. While more traditional republicans would consider such a measure as itself a form of "ethnicization" of public life [that] risks weakening the national unit' (Schnapper 1998: 78), a new wave of French political philosophers argue conversely that it is exclusion from public life that can lead to ethnicisation and social fragmentation (e.g. Audard 2001; Laborde 2008, 2013; Guérard de Latour 2009, 2013).

Inspired by the theoretical insights of cultural liberalism, this new wave of French political philosophy 'invit[es] French republicanism to be less sociologically naïve, that is, to acknowledge the power relations that make a sanctified distinction between the public and private spheres impossible' (Guérard de Latour 2009: 25). It does not seek to surrender to cultural liberalism, but rather to draw on its findings to theorise a new third-way model of republican multiculturalism with the necessary theoretical tools to reconcile traditional culture-blind normative principles on the one hand with the reality of an ethnoculturally non-neutral public sphere on the other.

Such is the aim, for example, of the model of critical republicanism developed by Laborde.

Critical republicanism is careful not to equate French cultural practices with universalism, and thereby accepts the idea that it is precisely because the public sphere is not culturally neutral that certain 'reasonable accommodations' in favour of minorities can be demands for justice. These accommodations, in so far as (and only in so far as) they re-establish equality do not 
break with republican logic but, on the contrary, deepen it. This is possible provided that one accepts that republican doctrine has a duty to advocate integration by means of common law and public institutions, not cultural assimilation and conformism. (Laborde 2013: 230-231)

Critical republicanism thus seeks to disentangle the political and cultural dimensions of integration, something also advocated by cultural liberals (e.g. Petrovic 2015: 47-49). At the same time, however, critical republicanism distinguishes itself from liberalism by drawing on the notion of non-domination developed by contemporary neo-republican theory in the anglophone world (Pettit 1997). Unlike liberalism, which prescribes the non-interference of the state in individuals' own conceptions of the good, critical republicanism seeks instead 'the reduction of majority domination [...] in so far as this has an impact on the rights and opportunities of members of minorities' (Laborde 2013: 241). It seeks to do this by means of 'a strategy that de-ethnicises the public sphere, which both deinstitutionalises the majority culture and mainstreams minority identities' (Laborde 2013: 239). Importantly, the recognition of minority cultures in the public sphere is thus not a goal per se; rather it is only condoned if required to offset the domination suffered by individual minority group members.

Unfortunately, critical republicanism is not a comprehensive theory of the management of cultural diversity. Where it claims to differ the most from Kymlicka's liberalism concerns the case of immigrants and their descendants. On the question of regional minorities, which are only referred to in passing, one is left to infer that the model would indeed follow Kymlicka in arguing for the recognition of aspects of regional cultures in the public sphere. There is nonetheless a distinctive aspect of critical republicanism particularly germane to France's regional linguistic minorities, namely the suggestion that it is institutions, instead of citizens, that should be "republicanized" as a matter of priority" (Laborde 2008: 14). This turning of the tables, which refocuses attention on the obligations of the state, is completely consistent with the approach advocated by the Charter for Regional or Minority Languages (José-Marie Woehrling, in Council of Europe 2004: 62; Oakes 2011a). One can thus surmise that a critical republican approach to regional languages would be in favour of ratification. But what might a new less rigid republican approach to regional languages look like more broadly?

\section{Towards a new republican approach to minority language rights}

Such an approach was proposed recently by Banai (2013). Like critical republicanism, Banai's model relies on a distinction between political or public life on the one hand and cultural life on the other, with the potential to allow for more recognition of regional languages in the public sphere. ${ }^{2}$ Indeed, crucial to her

\footnotetext{
${ }^{2}$ It is beyond the scope of this article to address the potentially problematic question of what the object of recognition would be, especially since loyalty to local dialects sometimes results in the rejection of standards developed specifically for minority language revitalisation (see Fishman 1997). Suffice it to say here that the promotion of a revived standard and dialect preservation need not be mutually exclusive but
} 
approach is the distinction she makes between public recognition and cultural recognition of minority languages. About the former, she explains that:

A speaker of a public language can expect her fellow citizens and representatives of public institutions to understand and interact with her in this language in matters related to the public or political life of their country and in the provision of public goods and services-for example, health, education, welfare, media and culture, law and administration. (Banai 2013: 202)

Cultural recognition, by contrast, allows speakers of non-public languages to 'have access to and sustain knowledge of their own language as an element of their identity and a resource for their personal and social lives' and typically requires 'funding for cultural centres and activities, some hours of schooling for children in the language as well as learning for adults, supplemented by support for media outlets' (Banai 2013: 203). This distinction between public and cultural recognition, combined with a concern for the vitality or what Banai terms the 'viability' of languages, leads her to propose three types of recognition (Banai 2013: 209):

1. public recognition of a language in a designated territory if (a) the language was present in that region and viable prior to the process of linguistic homogenisation; and (b) the language is still viable in the region today;

2. symbolic public recognition if (a) the language was present in that region and viable prior to the process of linguistic homogenisation; but (b) is no longer viable in the region today;

3. cultural recognition if (a) the language was not present in the territory prior to the process of linguistic homogenisation; or (b) the language was present in the territory prior to linguistic homogenisation but was not viable at that time.

Banai makes an attempt to deal with the question of historical injustice, something that sets her model apart from ahistorical or 'presentist' approaches to language rights. As May (2005: 322) explains, such approaches are 'particularly problematic because [they fail] to address adequately, if at all, the unavoidable historical and contemporary fact that the establishment of state-mandated or national languages is, in almost all cases, an inherently deliberate [...] political act and one, moreover, that clearly advantages some individuals and groups at the expense of others.' Banai (2013: 203) is thus right to note that minority languages like Breton have suffered from 'deliberate suppression'. That she then dismisses this

Footnote 2 continued

can be complementary goals (see Tulloch 2008 for a detailed discussion). In education, for example, the tendency in Brittany is to use the revived standard first, before introducing variation towards the end of primary and in secondary education, while in the Basque Country, local dialects tend to be used in earlier schooling with the unified standard introduced later (Ó hIfearnáin 2011: 100). Corsica has also attempted to deal with the problem of recognition of dialectal variation through the concept of 'polynomia' (Marcellesi 1984), which acknowledges multiple centres of authenticity and authority in Corsican, especially for the purposes of education. This is not to say that misrecognition is not still a problem in Corsica's polynomic model (Jaffe 2003), which brings us back to the benefit of a normative language policy approach in assessing which inevitable power relations are justified and which are not. 
fact on the grounds that these same languages are no longer viable nonetheless amounts to the same historical inevitability or fait accompli problem highlighted by May.

While few would argue that viability should not be a consideration to some extent, the problem here lies in Banai's definition of the notion. Despite her criticism of Kymlicka's notion of 'societal culture' for its inability to account for the claims of smaller linguistic communities, her own model seems to set the bar equally high. For Banai, viability means that a language should be able to sustain a 'full range of political and social institutions' (Banai 2013: 203), a criterion that clearly echoes the definition of a societal culture. The language also 'needs to be spoken by a sufficient number of people in an identifiable geographical area' (Banai 2013: 203); a minimum of 2 million people would be a plausible number in her view (Banai 2013: 211). Not only would these criteria disqualify Breton from full public recognition status; all of France's regional languages would in fact only be eligible for the two lesser types of recognition: symbolic public recognition and cultural recognition. Banai might differ from others with regard to her understanding of symbolic recognition, which for her includes public broadcasting, for example. Nonetheless, the reality is that there is a whole range of public recognition measures such as this that stress both the symbolic and instrumental value of minority languages, and that can help to offset the domination suffered by speakers despite the fact that their languages do not enjoy the level of vitality that Banai assumes is necessary.

Any attempt to rethink France's policies towards regional languages within a revised republican framework needs to be more ambitious that Banai's model in this respect. State claims to ethnocultural neutrality have been rightly shown to be illusory, especially in matters of language. But this does not mean that the public recognition of languages is a zero-sum game, that only sufficiently viable languages can enjoy public recognition that is more than merely symbolic. Certainly, the fact that there are only a limited number of 'good speakers' of Corsican did not preclude Via Stella, the Corsican digital television channel launched by the French state to much fanfare in 2007 (Blackwood 2008: 140), from proposing over 838 hours of Corsican-language and over 566 hours of French-Corsican bilingual programming in 2014 (DGLFLF 2015: 157). Such resources exist not as a replacement for the understandably richer reference resources that exist in French, but rather as a complement. The question of the public recognition of regional languages more broadly should be seen in similar complementary terms. In this way, all French citizens can participate in the negotiation of a truly inclusive public culture.

Banai's model also suffers from a lack of theoretical creativity regarding the role of the individual. For her, one of the ways that republicanism distinguishes itself from liberalism is through its resistance to 'the idea that the public and political realms are merely instruments to private ends' (Banai 2013: 200). Without losing sight of this ideal, there is nonetheless more room for manoeuvre here than Banai is willing to admit. Such an approach would require the rethinking of the notion of equality in particular. From the traditional universalist conception of equality that only recognises the individual as an abstract citizen, there would need to be some shift towards a more differentialist interpretation that is sensitive to the different situations in which individuals find themselves. In Italy and Spain, for example, 
these two conceptions of equality-formal versus real, material or substantiveexist side by side, complementing one another, not least in judicial matters related to the status of regional languages (Bertile 2008: 337-349). The notion of equality guaranteed in article 3 of the Italian Constitution, for example, 'should not be understood in the sense that the legislator cannot dictate different rules for the treatment of situations it deems to be different, by adapting the legal framework to various aspects of social life'. ${ }^{3}$ Similarly, in the Spanish Constitution, 'the principle of legal equality enshrined in article 14 refers initially to the universality of the law but does not prevent the legislator from contemplating the necessity or advisability of differentiating distinct situations and treating them differently, which in a social and democratic state of law can be considered essential for the effectiveness of the values that the Constitution considers higher. ${ }^{4}$ While France has traditionally chosen largely to reject such 'evolutionary methods of interpretation' (Constance Grewe, in Council of Europe 2004: 94), this would seem key to the feasibility of any more modest republican approach to regional languages in France.

\section{Conclusion}

As argued throughout this article, a normative language policy approach offers new insight into the question of minority language rights in France, not least through a critical assessment of key republican principles, many of which are in fact shared with liberalism. Because of the challenges it has faced itself over the last few decades, liberalism is well placed to make important contributions in at least four ways, as seen here. First, it can help to shift attention away from minority languages as cultural curiosities and refocus it on the actual needs of individuals who speak these languages. Second, it provides further moral justification for the promotion of regional languages in so far as this helps to make available a range of subjectively valued options for their speakers which, combined with the more generic options offered by universalist conceptions of citizenship, allow them to realise themselves fully and exercise their autonomy. Third, Kymlicka's notion of internal restriction helps to clarify the issues at stake when debating whether the teaching of regional languages should be optional or not. Finally, the observations made by cultural liberals that the state is not ethnoculturally neutral have prompted a new wave of French political philosophers to begin rethinking traditional republican principles so as to compensate for the unjust power relations which effectively compromise the equality of citizens in France today. While most of this work has to date focused on immigrants and their descendants, a similar normative approach should be applied to regional languages. Not only would this help to produce a more robust republicanism better suited to the modern world, it also has the potential to generate a distinctive model of minority language rights that both addresses the demands of

\footnotetext{
${ }^{3}$ Constitutional Court of Italy, judgment No. 3 of 16 January 1957, published in the Gazzetta Ufficiale 27 of 30 January 1957.

${ }^{4}$ Constitutional Court of Spain, judgment No. 34/1981 of 10 November 1981, published in the Boletín Oficial del Estado 277 of 19 November 1981.
} 
smaller autochthonous communities and justifies state intervention as an alternative to (liberal) non-interference as a means of counteracting the domination that prevents members of these communities from feeling part of mainstream public life. Such a model would not only be of benefit to France, but would also make a significant contribution to debates about minority language rights more broadly.

Acknowledgements I am grateful to Michelle Harrison and Aurélie Joubert for giving me the opportunity to present a version of this paper at the 'Regional Languages of France: Challenges and Opportunities in the Twenty-First Century' conference held at the University of Leicester in September 2015. I also wish to thank Yael Peled and the two anonymous reviewers for their comments on earlier drafts.

Open Access This article is distributed under the terms of the Creative Commons Attribution 4.0 International License (http://creativecommons.org/licenses/by/4.0/), which permits unrestricted use, distribution, and reproduction in any medium, provided you give appropriate credit to the original author(s) and the source, provide a link to the Creative Commons license, and indicate if changes were made.

\section{References}

Ager, D. E. (1999). Identity, insecurity and image: France and language. Clevedon: Multilingual Matters. Audard, C. (1999). French republicanism and 'thick' multiculturalism. In R. Bhargava, A. K. Bagchi, \& R. Sudarshan (Eds.), Multiculturalism, liberalism and democracy (pp. 116-137). Oxford: Oxford University Press.

Audard, C. (2001). The French Republic and the claims of diversity. In C. C. Gould \& P. Pasquino (Eds.), Cultural identity and the nation-state (pp. 85-108). Lanham, MD: Rowman and Littlefield Publishers.

Banai, A. (2013). Language recognition and fair terms of inclusion: minority languages in the European Union. In P. Balint \& S. G. de Latour (Eds.), Liberal multiculturalism and the fair terms of integration (pp. 194-210). Basingstoke: Palgrave Macmillan.

Barry, B. (2001). Culture and equality: An egalitarian critique of multiculturalism. Cambridge: Polity Press.

Baubérot, J. (2006). L'intégrisme républicain contre la laïcité. La Tour d'Aigues: Éditions de l'Aude.

Beiner, R. (2003). Liberalism, nationalism and citizenship: Essays on the problem of political community. Vancouver, BC: UBC Press.

Bertile, V. (2008). Les langues régionales ou minoritaires et constitution: France Espagne, Italie. Brussels: Bruyant.

Birnbaum, P. (2004). Between universalism and multiculturalism: The French model in contemporary political theory. In A. Dieckhoff (Ed.), The politics of belonging: Nationalism, liberalism, and pluralism (pp. 177-193). Lanham, MD: Lexington Books.

Blackwood, R. J. (2008). The state, the activists and the islanders. Dordrecht: Springer.

Bouchard, G. (1999). La nation québécoise au futur et au passé. Montréal: VLB éditeur.

Bruthiaux, P. (2009). Language rights in historical and contemporary perspective. Journal of Multilingual and Multicultural Development, 30(1), 73-85.

Carcassonne, G. (1998). Étude sur la compatibilité entre la Charte européenne des langues régionales ou minoritaires et la Constitution. Accessed February 21, 2016, from http://www.ladocumentation francaise.fr.

Carens, J. H. (2000). Culture, citizenship and community. A contextual exploration of justice as evenhandedness. New York, NY: Oxford University Press.

Cerquiglini, B. (1999a). Les langues de France. Rapport au Ministre de l'Education Nationale, de la Recherche et de la Technologie, et à la Ministre de la Culture et de la Communication. Paris: La documentation française. Accessed February 21, 2016, from http://www.ladocumentationfrancaise.fr.

Cerquiglini, B. (1999b). Basque, breton, corse, occitan, mais aussi créole et berbère: Qui a peur des langues minoritaires? Interview with Bernard Cerquiglini. Le Nouvel Observateur, 1808, 1 July.

Cohen, J. A. (2001). Value judgements and political assessments about national models of citizenship: The U.S. and French cases. In C. C. Gould \& P. Pasquino (Eds.), Cultural identity and the nationstate (pp. 109-130). Lanham, MD: Rowman \& Littlefield Publishers. 
Collectivité territoriale de Corse. (2013a). Proposition de statut pour la coofficialité et la revitalisation de la langue corse. (Rapport No. 2013/O1/066) Ajaccio: Assemblée de Corse. Accessed February 21, 2016, from http://www.corse.fr/file/137099.

Collectivité territoriale de Corse. (2013b). Enquête sociolinguistique sur la langue corse: compétences, usages et représentations. [Ajaccio]: Collectivité territoriale de Corse. Accessed February 21, 2016, from http://www.corse.fr/Consultez-l-enquete-sociolinguistique-sur-la-langue-corse-competencesusages-et-representations_a4044.html.

Collectivité territoriale de Corse. (2014). Planification lingua 2020. (Rapport No. 2014/E4/189). Ajaccio: Assemblée de Corse. Accessed February 21, 2016, from www.corse.fr/file/161442.

Council of Europe. (2004). The European charter for regional or minority languages and the French dilemma: Diversity v. unicity-which language(s) for the Republic?. Strasbourg: Council of Europe.

De Schutter, H. (2007). Language policy and political philosophy: On the emerging linguistic justice debate. Language Problems and Language Planning, 31(1), 1-23.

Délégation générale à la langue française et aux langues de France (DGLFLF). (2015). Rapport au Parlement sur l'emploi de la langue française. Paris: DGLFLF. Accessed June 7, 2016, from http:// www.culturecommunication.gouv.fr/Politiques-ministerielles/Langue-francaise-et-langues-de-France.

Edwards, J. (2003). Contextualizing language rights. Journal of Human Rights, 2(4), 551-571.

Fishman, J. A. (1997). Reversing language shift. Clevedon: Multilingual Matters.

Geisser, V. (2005). Ethnicité républicaine versus République ethnique? Mouvements, 38, 19-25.

Giordan, H. (2008). Les langues régionales dans la constitution: Un pas en avant très ambigu. Diasporiques, 3(nouvelle série), 25-30.

Giordan, H., \& Lafont, R. (1999). La France intégriste. Libération, 5 July.

Grin, F. (2005). Linguistic human rights as a source of policy guidelines: A critical assessment. Journal of Sociolinguistics, 9(3), 448-460.

Guérard de Latour, S. (2009). Vers la République des différences. Toulouse: Presses universitaires du Mirail.

Guérard de Latour, S. (2013). Is multiculturalism un-French? Towards a neo-republican model of multiculturalism. In P. Balint \& S. Guérard de Latour (Eds.), Liberal multiculturalism and the fair terms of integration (pp. 139-156). Basingstoke: Palgrave Macmillan.

Gutmann, A. (1980). Children, paternalism, and education: A liberal argument. Philosophy \& Public Affairs, 9(4), 338-358.

Jaffe, A. (2003). Misrecognition unmasked? 'Polynomic' language, expert statuses and orthographic practices in Corsican schools. Pragmatics, 13(4), 515-537.

Jennings, J. (2000). Citizenship, republicanism and multiculturalism in contemporary France. British Journal of Political Science, 30(4), 575-598.

Judge, A. (2007). Linguistic policies and the survival of regional languages in France and Britain. Basingstoke: Palgrave Macmillan.

Kahn, J.-F. (2000). L'infâme magouille du 12 juillet. Marianne, 24 July.

Koubi, G. (2004). The management of cultural diversity in France. In A. Dieckhoff (Ed.), The politics of belonging: Nationalism, liberalism, and pluralism (pp. 195-220). Lanham, MD: Lexington Books.

Kymlicka, W. (1995). Multicultural citizenship. Oxford: Clarendon Press.

Kymlicka, W., \& Patten, A. (Eds.). (2003). Language rights and political theory. Oxford: Oxford University Press.

Laborde, C. (2008). Critical republicanism: The hijab controversy and political philosophy. Oxford: Oxford University Press.

Laborde, C. (2013). Républicanisme critique et multiculturalisme libéral. In S. G. de Latour (Ed.), Le multiculturalisme a-t-il un avenir? (pp. 227-242). Paris: Hermann.

Määttä, S. K. (2005). The European Charter for Regional or Minority Languages, French language laws, and national identity. Language Policy, 4(2), 167-186.

Marcellesi, J.-B. (1984). La définition des langues en domaine roman: les enseignements à tirer de la situation corse. In J.-C. Bouvier, et al. (Eds.), Actes du XVIIe congrès international de linguistique et de philologie romanes (pp. 309-314). Aix-en-Provence: Université de Provence.

May, S. (2005). Language rights: Moving the debate forward. Journal of Sociolinguistics, 9(3), 319-347.

Meistersheim, A. (2008). Du riacquistu au désenchantement. Une société en quête de repères. Ethnologie française, 38(3), 407-413.

Mill, J. S. (1991 [1861]). Considerations on representative government. In J. Gray (Ed.), On Liberty and other essays (pp. 203-467). Oxford: Oxford University Press. 
Mill, J. S. (1991 [1859]). On liberty. In J. Gray (Ed.), On Liberty and other essays (pp. 5-128). Oxford: Oxford University Press.

Nadeau, C. (n.d.). Une école Diwan à Paris: Pourquoi? Accessed February 21, 2016, from http:// diwanparis.free.fr/pourquoi.html.

Oakes, L. (2011a). Regional languages, the European Charter and Republican values in France today. In C. Norrby \& J. Hajek (Eds.), Uniformity and diversity in language policy: Global perspectives (pp. 68-85). Bristol: Multilingual Matters.

Oakes, L. (2011b). Promoting language rights as fundamental individual rights: France as a model? French Politics, 9(1), 50-68.

Oakes, L., \& Peled, Y. (forthcoming). Normative language policy: Ethics, politics, principles. Cambridge: Cambridge University Press.

Ó hIfearnáin, T. (2011). In C. Norrby \& J. Hajek (Eds.), Uniformity and diversity in language policy: Global perspectives (pp. 93-108). Bristol: Multilingual Matters.

Patten, A. (2001). Political theory and language policy. Political Theory, 29, 691-715.

Patten, A. (2014). Equal recognition: The moral foundations of minority rights. Princeton, NJ: Princeton University Press.

Peled, Y. \& Weinstock, D. (Eds.) (in press). Language ethics.

Petrovic, J. E. (2015). A post-liberal approach to language policy in education. Bristol: Multilingual Matters.

Petrovic, J. E., \& Kuntz, A. M. (2013). Strategies of reframing language policy in the liberal state: A recursive model. Journal of Language and Politics, 12(1), 126-146.

Pettit, P. (1997). Republicanism: A theory of freedom and government. Oxford: Oxford University Press.

Rawls, J. (1971). A theory of justice. Cambridge, MA: Belknap Press.

Raz, J. (1986). The morality of freedom. Oxford: Oxford University Press.

Renaut, A. (2000). Le débat français sur les langues régionales. In W. Kymlicka \& S. Mesure (Eds.), Les identités culturelles (Comprendre, 1) (pp. 381-400). Paris: Presses universitaires de France.

Ricento, T. (2000). Historical and theoretical perspectives in language policy and planning. Journal of Sociolinguistics, 4(2), 196-213.

Ricento, T., Peled, Y., \& Ives, P. (Eds.) (2014). Language policy and political theory [Special issue]. Language Policy, 13(4).

Sandel, M. (1982). Liberalism and the limits of justice. Cambridge: Cambridge University Press.

Schlesinger, A. M. Jr. (1998). The disuniting of America: Reflections on multicultural society. [Revised and enlarged edition]. New York, NY: W. W. Norton.

Schnapper, D. (1998). Community of citizens: On the modern idea of nationality. New Brunswick, NJ: Transaction.

Schnapper, D. (2000). Qu'est-ce que la citoyenneté? (Folio actuel 75). Paris: Gallimard.

Seymour, M. (2000). Le libéralisme, la politique de la reconnaissance, et le cas du Québec. In W. Kymlicka \& S. Mesure (Eds.), Les identités culturelles (Comprendre, 1) (pp. 119-138). Paris: Presses universitaires de France.

Taylor, C. (1994). The politics of recognition. In C. Taylor, K. A. Appiah, J. Habermas, S. C. Rockerfeller, M. Walzer \& S. Wolf (Ed. and introduced by A. Gutmann), Multiculturalism: Examining the politics of recognition (pp. 25-73). Princeton, NJ: Princeton University Press.

Tulloch, S. (2008). Preserving dialects of endangered languages. In A. J. Liddicoat \& R. B. Baldauf Jr. (Eds.), Language planning and policy: Language planning in local contexts (pp. 95-112). Clevedon: Multilingual Matters.

Van Parijs, P. (2011). Linguistic justice for Europe and for the world. Oxford: Oxford University Press. Woehrling, J.-M. (1999). La Charte est-elle compatible avec l'article 2 de la Constitution française? In J. Bouvier et al. (Eds.), Langues régionales: Langues de France, langues d'Europe. Paris: Bpi-Centre Pompidou. Accessed July 31, 2015, from http://www.bpi.fr.

Leigh Oakes is Reader in French and Linguistics at Queen Mary University of London. His research focuses on normative language policy, language and national identity, and language attitudes and ideologies. He is the author of Normative Language Policy: Ethics, Politics, Principles (with Y. Peled, forthcoming, Cambridge University Press), Language, Citizenship and Identity in Quebec (with J. Warren, 2007, Palgrave Macmillan) and Language and National Identity: Comparing France and Sweden (2001, John Benjamins). 